\title{
A 5-year follow-up of vulval swelling due to extraskeletal myxoid chondrosarcoma: A rare case report
}

\author{
DANIELLE O'NEILL ${ }^{1}$, MIRNA ELGHOBASHY ${ }^{2}$, HUYAM ABDELSALAM ${ }^{3}$, \\ MARIE METELKO $^{4}$ and ALAA EL-GHOBASHY ${ }^{1}$ \\ ${ }^{1}$ Department of Gynaecological Oncology, The Royal Wolverhampton NHS Trust, WV10 0QP Wolverhampton; \\ ${ }^{2}$ University of Birmingham Medical School, B15 2TT Birmingham; \\ ${ }^{3}$ Department of Pathology, Glan Clwyd Hospital, LL18 5UJ Bodelwyddan; \\ ${ }^{4}$ Department of Radiology, Royal Shrewsbury Hospital, SY3 8XQ Shrewsbury, UK
}

Received December 12, 2018; Accepted February 15, 2019

DOI: $10.3892 / \mathrm{mco} .2019 .1822$

\begin{abstract}
Vulval extraskeletal myxoid chondrosarcoma (EMC) is a rare cause of vulval swelling, reported $<10$ times in the literature to date. EMC in this location is frequently misdiagnosed due to its rarity, and patients may incur delays in diagnosis and treatment. We herein present the diagnosis and management of the case of vulval EMC in a 42-year-old Caucasian female patient who presented in 2011 with a swelling on the right labium majus. The tumour was initially misdiagnosed as a Bartholin's cyst and managed conservatively. The tumour was ultimately diagnosed as EMC and treated by radical surgical excision and adjuvant radiotherapy. The aim of the present study was to report the results after a long-term follow-up period and review the available relevant literature.
\end{abstract}

\section{Introduction}

Vulval cancer is a rare malignancy, with $\sim 1,300$ new cases diagnosed annually in the UK (1). The most common histological subtype is squamous cell carcinoma, accounting for $90 \%$ of all cases. Sarcomas encompass a group of tumours of mesenchymal origin and account for only $3 \%$ of cancers affecting the female genital tract (2). Most sarcomas affect the uterine body; however, $1-3 \%$ of the cases affect the vulva (3). Extraskeletal myxoid chondrosarcoma (EMC) is a rare subtype of sarcoma, which was first described in 1972 by Enzinger and Shiraki (4). Since that time, there have been few reported cases of this rare tumour in the literature, and fewer still reported to affect the female genital tract (Table I) (5-10). EMCs tend to affect

Correspondence to: Mr. Alaa El-Ghobashy, Department of Gynaecological Oncology, The Royal Wolverhampton NHS Trust, Wolverhampton Road, Heath Town, WV10 0QP Wolverhampton, UK E-mail: alaaelghobashy@nhs.net

Key words: vulva, swelling, myxoid chondrosarcoma patients in the 6 th decade of life and have a predilection for the deep soft tissue of the lower extremities.

Histologically, these tumours are described as having a multinodular architecture with mucoid material and foci of haemorrhage, so that they may be initially misdiagnosed as organised haematomas (10). Misdiagnosis is common (8) and preoperative diagnosis is very difficult due to the rarity of this tumour and its presentation as a slow-growing painless lump (6). Identifying reciprocal translocation of $t(9 ; 22)$ (q22-31;q11-12) on immunohistochemistry has characterized these tumours as a class distinct from skeletal myxoid chondrosarcoma and aids in their diagnosis (11).

EMCs tend to be relatively chemotherapy-resistant and, therefore, the first-line treatment is surgical resection with adjuvant radiotherapy. Evidence suggests EMC has a high propensity for metastasis, mainly to the lungs, lymph nodes or bone, particularly if further characterised as high-grade, disproving earlier beliefs that it was associated with good prognosis. The estimated progression-free survival rates at 3 , 4, 6 and 9 months were 69, 65, 40 and 26\%, respectively (12). There are limited long-term follow-up and survival data on these patients, and even fewer on tumours affecting the female genital tract. The survival at 5, 10 and 15 years has been reported to be 82,65 and $58 \%$, respectively, for patients with EMC, irrespective of the site (12).

The aim of the present study was to present a case of vulval EMC to add to the currently limited scientific knowledge on this rare condition.

\section{Case report}

In 2011, a 42-year-old Caucasian woman presented with a swelling on the right labium majus, which was initially considered to be a Bartholin gland/duct cyst and was managed conservatively. The patient was reviewed 7 months later and underwent drainage and marsupialization under general anaesthesia, resulting in extensive bruising of the vulva. The patient was managed medically with antibiotics and non-steroidal anti-inflammatory medication, and her condition resolved after 3 weeks. Six months later, the patient presented with another vulval mass at the site of the previous 
Table I. Literature review of reported cases of vulval extraskeletal myxoid chondrosarcoma.

\begin{tabular}{|c|c|c|c|c|c|c|c|c|c|}
\hline Author (Refs.) & Year & $\begin{array}{c}\text { Patient } \\
\text { no. }\end{array}$ & $\begin{array}{l}\text { Age, } \\
\text { years }\end{array}$ & Site & Management & Margins & $\begin{array}{l}\text { Adjuvant } \\
\text { treatment }\end{array}$ & $\begin{array}{c}\text { Follow-up } \\
\text { (months) }\end{array}$ & Recurrence \\
\hline Santacruz et al (5) & 2005 & 1 & 46 & $\begin{array}{l}\text { Vulva/ } \\
\text { periclitoral }\end{array}$ & $\begin{array}{l}\text { Surgical } \\
\text { excision }\end{array}$ & Clear & Nil & 6 & No \\
\hline Khan et al (6) & 2011 & 1 & 66 & $\begin{array}{l}\text { Labium } \\
\text { majus }\end{array}$ & $\begin{array}{l}\text { Surgical } \\
\text { excision }\end{array}$ & Clear & $\begin{array}{l}\text { Refused } \\
\text { by patient }\end{array}$ & 12 & No \\
\hline Sawada et al (7) & 2011 & 1 & 24 & $\begin{array}{l}\text { Right labium } \\
\text { majus }\end{array}$ & $\begin{array}{l}\text { Modified } \\
\text { vulvectomy }\end{array}$ & Clear & Nil & 24 & No \\
\hline \multirow[t]{3}{*}{ Jeh et al (8) } & 2013 & 3 & 68 & $\begin{array}{l}\text { Right labium } \\
\text { majus }\end{array}$ & $\begin{array}{l}\text { Surgical } \\
\text { excision }\end{array}$ & Clear & Nil & 30 & No \\
\hline & & & 52 & $\begin{array}{l}\text { Left labium } \\
\text { majus }\end{array}$ & $\begin{array}{l}\text { Surgical } \\
\text { excision }\end{array}$ & Clear & Nil & 24 & No \\
\hline & & & 59 & $\begin{array}{l}\text { Left labium } \\
\text { majus }\end{array}$ & $\begin{array}{l}\text { Surgical } \\
\text { excision }\end{array}$ & Clear & Nil & 24 & No \\
\hline \multirow[t]{2}{*}{ Dotlic et al (9) } & 2013 & 2 & 52 & $\begin{array}{l}\text { Left labium } \\
\text { majus }\end{array}$ & $\begin{array}{l}\text { Surgical } \\
\text { excision }\end{array}$ & $\begin{array}{l}\text { Not } \\
\text { mentioned }\end{array}$ & $\begin{array}{l}\text { Repeated } \\
\text { surgery due } \\
\text { to recurrence } \\
\text { and } 7 \text { cycles } \\
\text { chemotherapy }\end{array}$ & 12 & $\begin{array}{l}\text { Yes - local and } \\
12 \text { months } \\
\text { following } \\
\text { diagnosis } \\
\text { lung metastasis } \\
\text { causing death }\end{array}$ \\
\hline & & & 52 & Left vulva & $\begin{array}{l}\text { Surgical } \\
\text { excision }\end{array}$ & $\begin{array}{l}\text { Not } \\
\text { mentioned }\end{array}$ & $\begin{array}{l}\text { Not } \\
\text { mentioned }\end{array}$ & $\begin{array}{c}\text { Not } \\
\text { mentioned }\end{array}$ & \\
\hline Villert et al (10) & 2015 & 1 & 32 & $\begin{array}{l}\text { Labia } \\
\text { majora }\end{array}$ & $\begin{array}{l}\text { Surgical } \\
\text { excision }\end{array}$ & $\begin{array}{l}\text { Not } \\
\text { mentioned }\end{array}$ & $\begin{array}{l}\text { Intraoperative } \\
\text { radiotherapy }\end{array}$ & 12 & $\begin{array}{l}5 / 12 \text { post-op } \\
\text { inguinal } \\
\text { node treatment: } \\
\text { excision/ } \\
\text { radiotherapy }\end{array}$ \\
\hline Present case & 2018 & 1 & 42 & $\begin{array}{l}\text { Right labium } \\
\text { majus }\end{array}$ & $\begin{array}{l}\text { Surgical } \\
\text { excision }\end{array}$ & $\begin{array}{l}\text { Close surgical } \\
\text { deep resection } \\
\text { margin }\end{array}$ & Radiotherapy & 60 & No \\
\hline
\end{tabular}

excision and underwent exploration and biopsy under anaesthesia. The results revealed a myxoid tumour, potentially of sarcoid origin. A computed tomography (CT) scan of the abdomen and pelvis did not demonstrate any evidence of metastasis. The case was discussed at a multidisciplinary tumour board to plan further management. The patient was referred to a subspecialist surgeon in Gynaecological Oncology for surgical excision. A planned magnetic resonance imaging (MRI) angiogram was performed to assess the extent and vascularity of the tumour. The T2-weighted sagittal images showed a well-defined lobulated high-signal mass with a low-signal capsule and an internal high signal, similar to that of the bladder (Fig. 1).

Intraoperatively, a 7x5-cm lobulated, vascular vulval mass was detected in the right labium majus. The tumour was firmly adherent to the periosteum of the inferior pubic ramus. A satisfactory resection of the tumour (including the periosteum) was performed, with no macroscopic residual disease. Histological examination revealed a soft tissue mass, sized 70x50x45 mm, composed of myxoid tissue arranged in lobules with fibrous septa. Examination under high-power magnification (x40) revealed cord/lace-like arrangement of small rounded and spindle cells in a myxoid-rich matrix. There was a close microscopic deep excision margin, limited by the periosteum (Fig. 2).

Immunostaining revealed strong positivity for vimentin; however, S-100, oestrogen receptor (ER), desmin and smooth muscle actin were negative. FISH analysis for Ewing's sarcoma and FUS gene (implicated in myxoid liposarcoma and fibromyxoid sarcoma) revealed that both genes were intact. The final histological diagnosis was low-grade EMC.

The patient's condition was further discussed at the central and regional multi-disciplinary team meetings, and it was recommended that she received adjuvant external-beam pelvic radiotherapy (45 Gy in 25 sessions) due to the close deep resection margins. A postoperative MRI demonstrated no evidence of residual tumour. The surveillance follow-up included 6-monthly clinical examinations and yearly $\mathrm{CT}$ scans. The patient remains 


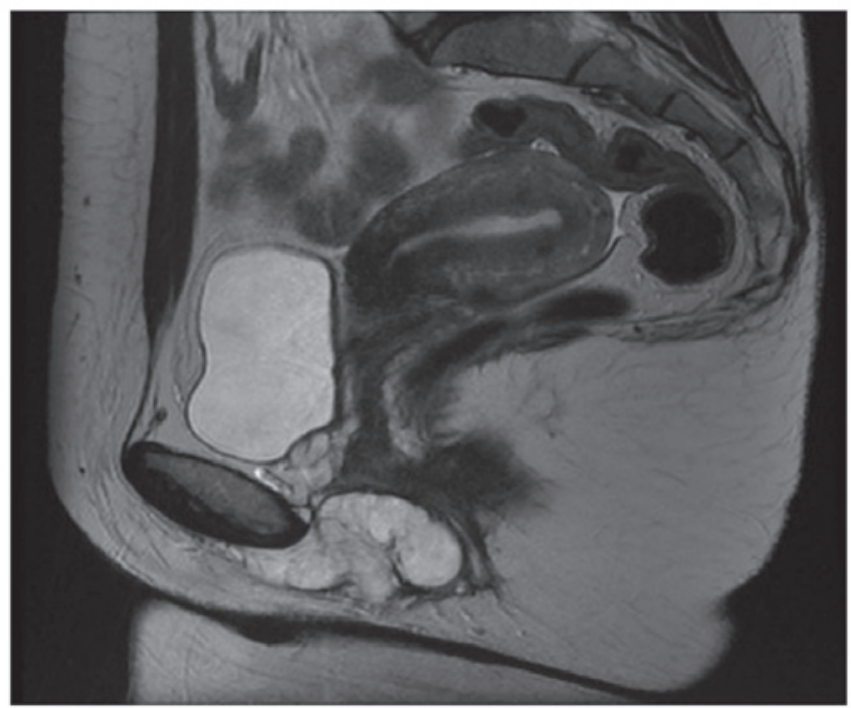

Figure 1. Magnetic resonance imaging, T2 sagittal section showing a lobulated high-signal well-defined mass with a low-signal capsule, with an internal high signal similar to that of the bladder.

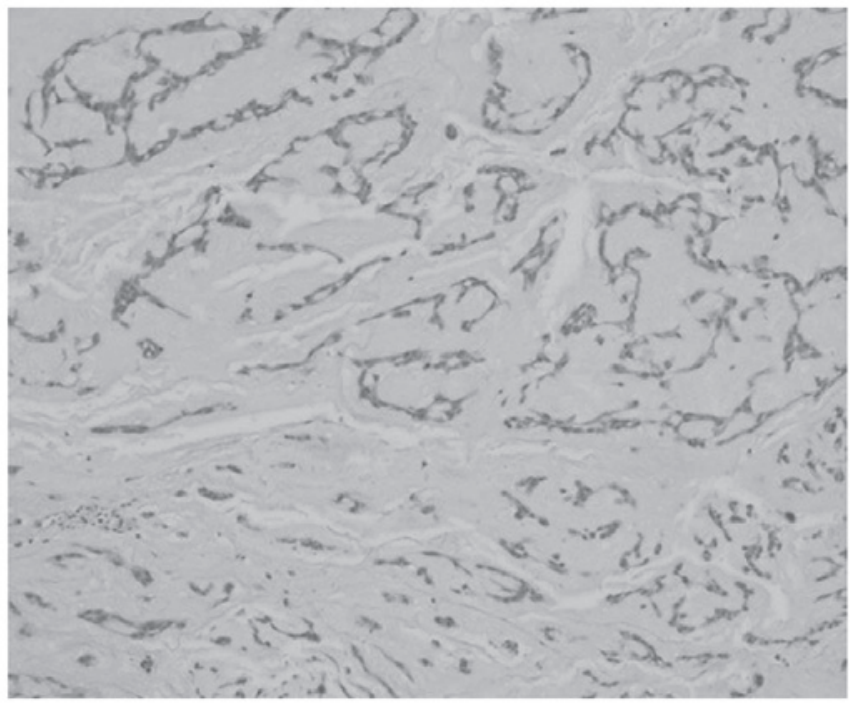

Figure 2. Histological examination showing small rounded/spindle cells in cord/lace-like arrangement in a myxoid-rich matrix. Magnification, $\mathrm{x} 40$.

asymptomatic and with no evidence of recurrent disease 60 months following her initial treatment. The last clinical follow up was 10 November 2018.

\section{Discussion}

Upon reviewing the existing literature, most cases of vulval EMC usually present as painless, smooth, 'globular' mobile masses affecting the labia majora. They do not appear to have a predilection for a specific age or menopausal status. Most cases were treated by complete surgical resection with adequate margins. The present case differs, as the mass was firmly adherent to the periosteum of the inferior pubic ramus, rendering complete surgical excision challenging and potentially debilitating. The tumour was resected to the periosteum and the patient was offered adjuvant radiotherapy postoperatively. The diagnosis of EMC may be confirmed through immunohistochemical staining for vimentin, neuron-specific enolase, S-100 protein and mucicarmine, as described in previous cases. The present case exhibited strong staining for vimentin. The opinion of the histopathology team was that the negative genetic tests could be due to the extraskeletal location of the tumour. Whilst the molecular studies performed in this case were not suggestive of EMC, the histological appearance and staining were consistent, confirming the diagnosis.

The decision to offer adjuvant radiotherapy was considered as an acceptable option, as the patient was a young woman and radical excision with microscopic clear margins could not be guaranteed.

To the best of our knowledge, this is the longest follow-up (60 months) of a patient with confirmed EMC in the literature to date, and demonstrates that surgical resection with adjuvant radiotherapy can achieve long-term remission. However, more cases are required to assess the need for adjuvant therapy and the required length of follow-up to detect recurrence. The possibility of an EMC should be included in the differential diagnosis of women presenting with a smooth, soft and vascular vulval mass, and surgical excision with histological assessment is advised to avoid misdiagnosis.

\section{Acknowledgements}

Not applicable.

\section{Funding}

No funding was received.

\section{Availability of data and materials}

Not applicable.

\section{Authors' contributions}

AEG was involved in the conception of the study. HA and MM were involved in the diagnosis of the patient. MEG was involved in the literature review and writing of the article. DON was involved in the literature review and writing of the article. All the authors have read and approved the final version of this manuscript.

\section{Ethics approval and consent to participate}

Not applicable.

\section{Patient consent for publication}

Verbal consent has been obtained for publication of the case and associated photographs from the patient.

\section{Competing interests}

The authors declare that they have no financial interests or industrial affiliations to disclose. 


\section{References}

1. Cancer Research UK. Vulval cancer statistics. http://www. cancerresearchuk.org/health-professional/cancer-statistics/ statistics-by-cancer-type/vulval-cancer. Accessed Sep 14, 2018.

2. Salehin D, Haugk C, William M, Hemmerlein B, Thill M, Diedrich K and Friedrich M: Leiomyosarcoma of the vulva. Eur J Gynaecol Oncol 33: 306-308, 2012.

3. Chokoeva AA, Tchernev G, Cardoso JC, Patterson JW, Dechev I, Valkanov S, Zanardelli M, Lotti T and Wollina U: Vulvar sarcomas: Short guideline for histopathological recognition and clinical management. Part 2. Int J Immunopathol Pharmacol 28: 178-186, 2015.

4. Enzinger FM and Shiraki M: Extraskeletal myxoid chondrosarcoma. An analysis of 34 cases. Hum Pathol 3: 421-435, 1972.

5. Santacruz MR, Proctor L, Thomas DB and Gehrig PA: Extraskeletal myxoid chondrosarcoma: A report of a gynecologic case. Gynecol Oncol 98: 498-501, 2005.

6. Khan AS, Bakhshi GD, Shaikh A, Khan AA, Khan AA and Chitale A: Extraskeletal chondrosarcoma of labium majus. Case Rep Pathol 2011: 429562, 2011

7. Sawada M, Tochigi N, Sasajima Y, Hasegawa T, Kasamatsu T and Kitawaki J: Primary extraskeletal myxoid chondrosarcoma of the vulva. J Obstet Gynaecol Res 37: 1706-1710, 2011.
8. Jeh EA, Lee YJ, Kim HY, Kim A and Lee JH: Primary extraskeletal mesenchymal chondrosarcoma of the vulva. Obstet Gynecol Sci 56: 345-348, 2013.

9. Dotlic S, Gatalica Z, Wen W, Ghazalpour A, Mangham C, Babic D, Zekan J and Vranic S: Extraskeletal myxoid chondrosarcoma of the vulva with PLAG1 gene activation: Molecular genetic characterization of 2 cases. Appl Immunohistochem Mol Morphol 22: 537-542, 2014.

10. Villert A, Kolomiets L, Vasilyev N, Perelmuter V and Savenkova O: Extraskeletal myxoid chondrosarcoma of the vulva: A case report. Oncol Lett 10: 2095-2099, 2015.

11. Antonescu CR, Argani P, Erlandson RA, Healey JH, Ladanyi M and Huvos AG: Skeletal and extraskeletal myxoid chondrosarcoma: A comparative clinicopathologic, ultrastructural, and molecular study. Cancer 83: 1504-1521, 1998.

12. Drilon AD, Popat S, Bhuchar G, D'Adamo DR, Keohan ML, Fisher C, Antonescu CR, Singer S, Brennan MF, Judson I, et al: Extraskeletal myxoid chondrosarcoma: A retrospective review from 2 referral centers emphasizing long-term outcomes with surgery and chemotherapy. Cancer 113: 3364-3371, 2008. 